\title{
TAC1 wt Allele
}

National Cancer Institute

\section{Source}

National Cancer Institute. TAC1 wt Allele. NCI Thesaurus. Code C52389.

Human TAC1 wild-type allele is located within 7q21-q22 and is approximately $8 \mathrm{~kb}$ in length. This allele, which encodes protachykinin-1 protein, is involved in the mediation of both neuronal excitation and vasodilatation. 